
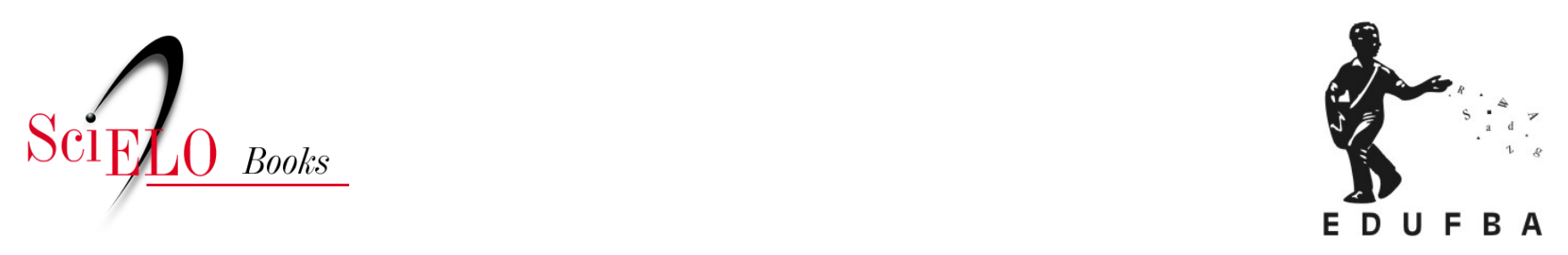

\title{
A literatura e as constelações familiares: como instaurar outros "melhores mundos possíveis"
}

\author{
Renata Pimentel
}

\section{SciELO Books / SciELO Livros / SciELO Libros}

PIMENTEL, R. A literatura e as constelações familiares: como instaurar outros "melhores mundos possíveis". In: MESSEDER, S., CASTRO, M.G., and MOUTINHO, L., orgs. Enlaçando sexualidades: uma tessitura interdisciplinar no reino das sexualidades e das relações de gênero [online]. Salvador: EDUFBA, 2016, pp. 201-221. ISBN: 978-85-232-1866-9.

https://doi.org/10.7476/9788523218669.0011.

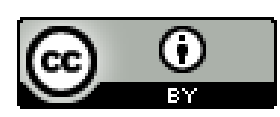

All the contents of this work, except where otherwise noted, is licensed under a Creative Commons Attribution $\underline{4.0 \text { International license. }}$

Todo o conteúdo deste trabalho, exceto quando houver ressalva, é publicado sob a licença Creative Commons Atribição 4.0. 


\title{
A literatura e as constelações familiares: \\ como instaurar outros \\ "melhores mundos possíveis"
}

\author{
渵 \\ Renata Pimentel
}

\section{Reconhecendo o terreno}

Tão logo um indivíduo trava contato com uma obra de arte, mundos se põem em relação: por vezes de estranhamento, de reconhecimento ou até de confronto. Mas o que faz um leitor, quando põe a máquina literária a funcionar? Torna-se, ele próprio, um dos construtores dos mundos "possíveis" e imaginados que lhe são apresentados. Nem sempre, porém, recebe pacificamente ou identifica-se com os ingredientes deste universo. Como diz Renato Cordeiro Gomes (I994, p. I5): “É arrastado, 
enquanto leitor, pelo movimento permutacional no mundo vicário dos signos. $\mathrm{O}$ jogo da circulação da linguagem se descentra e possibilita novas leituras". É instaurada uma espécie de jogo, no qual o leitor se converte em peça fundamental dos sentidos, como uma espécie de espião, flâneur, voyeur ou penetra. Ainda nas palavras de Renato Gomes (1994, p. 15), referindose a si próprio em sua experiência: “...constituo-me tal qual um eu à deriva, que, embora não solto no espaço e no tempo, inscreve-se no movimento da dança, entre o deslocar e o estatelar."

Mas é preciso estar atento: deslocamentos exigem escolhas e implicam surpresas. Por mais planejamento que se faça, o inesperado surge; e, mais ainda, se estamos situados neste particular terreno que é a arte, cujas relações são muito estreitas, diversas e imbricadas quanto aos mais variados planos da vida humana: espiritual, ética, moral, mundana, social, política, econômica. Para além de ser testemunho e legado cultural do ser humano, a obra de arte traz em si as idiossincrasias e contradições dos tempos e contextos em que foi criada e, por sua potência transtemporal, presentifica-se a cada nova recepção e passa a revelar também aspectos deste particular momento em que é "posta em funcionamento" pelo seu leitor/público.

Algumas manifestações artísticas, ainda, em seu caráter transtemporal e multifacetado como discurso/representação, valem como terreno de luta política e humana por direitos. As relações entre a produção literária e a ordem de valores (como já apontado) são inúmeras e multifacetadas: desde servindo a projetos de dominância quanto os questionando e propondo novos paradigmas. Mas certo conjunto de obras nessa linguagem artística, muitas vezes se vê reduzido ou diminuído em sua relevância, ao dissociar-se de concepções hegemônicas interessadas na manutenção da "moral dominante" - do status quo -, ou mesmo ao contrapor-se a estes valores. Precisamente neste último conjunto estão as obras que nos interessarão e ocuparão nossas reflexões.

Nosso enfoque recai sobre obras que recebem constantemente "adjetivações reducionistas” a estigmatizá-las (literatura gay/homossexual/lésbica). Esses rótulos parecem ser usados para depreciar e disfarçar a importância 
objetiva de uma produção artística que reflete sobre os interditos sociais, sobre olhares que revelam as "normas" e suas arbitrariedades. Se aqui vamos pensar a literatura e o modo como as configurações familiares (particularmente as homoparentais) nela aparecem, precisamos ter atentos os sentidos da "peça-leitor" que somos para fazer funcionar a engrenagem e perceber os tantos questionamentos gerados a partir desse universo ficcional.

Podemos e devemos lembrar que em épocas distintas as relações estabelecidas entre os artistas e o financiamento/status e a recepção de suas atividades se configuraram em bases diferentes, modificadas ao longo das transformações sociais e econômicas em cada tempo, lugar, povo, cultura. Tomemos um breve recorte a partir dos séculos XVII e XVIII, quando imperava o mecenato a eleger e sustentar os pintores, compositores, poetas. É relativamente fácil supor que boa parte desses criadores buscava agradar quem lhes financiava, mesmo quando enxergava mazelas e injustiças. Mesmo assim, havia artistas que se contrapunham ao código moral estabelecido e impunham reflexões incômodas. Mas tratava-se de outra ordem, o acesso às artes era restrito demais à corte. Com a Revolução Francesa e a tomada de poder pelos burgueses, começa o avanço avassalador do poder do capital, o império do mercado - iniciado já no sistema mercantil convertido em capitalismo - transforma a vida do artista que passa a precisar se estabelecer no mercado e comercializar sua obra de arte.

A literatura romântica produzida pelos burgueses no século XIX (tanto no contexto europeu, quanto no da colônia ultramarina, convenientemente "alçada a Reino Unido" ou, em seguida, transformada em império “independente") revela, então, o projeto político-econômico moralista da família, do casamento como um negócio que envolvia educar as mulheres para se manterem reprodutoras e guardiãs do lar, fiéis aos seus senhores/ maridos, pois a prole precisaria ser legítima, para garantir a condição de herdar os bens familiares. ${ }^{\text {I }}$

1 Embora haja a dominante literatura folhetinesca e os romances para educar o público-leitor feminino aos valores da fidelidade (como na obra de José de Alencar); há as irônicas 
Em sua História da sexualidade (volume I - A Vontade de saber), Michel Foucault (I997, p. 9-IO) principia pela retomada de parte do mesmo percurso aqui evocado, indicando-nos como herdeiros e ainda suscetíveis de submissão à era vitoriana²:

A sexualidade é, então, cuidadosamente encerrada. Muda-se para dentro de casa. A família conjugal a confisca. E absorve-a, inteiramente, na seriedade da função de reproduzir. [...] O casal, legítimo e procriador, dita a lei. Impõe-se como modelo, faz reinar a norma, detém a verdade [...] No espaço social, como no coração de cada moradia, um único lugar de sexualidade reconhecida, mas utilitário e fecundo: o quarto dos pais. Ao que sobra só resta encobrir-se.[...] E se o estéril insiste, e se mostra demasiadamente, vira anormal: receberá este status e deverá pagar as sanções.

O discurso sobre o sexo vai ganhando contornos e regras: há lugares em que ele é silenciado, mas em outros "o essencial é a multiplicação dos discursos sobre o sexo no próprio campo do exercício do poder". (FOUCAULT, I997, p. 22) Logo, por razões políticas, econômicas e até técnicas, o sexo entra na ordem do dia, literalmente, pois ele precisa ser vigiado, prescrito no funcionamento interessante à lógica das sociedades. A polícia, a medicina, a igreja e as leis vão gerir a vida e o sexo, para regular o estabelecido por estas instâncias de poder como sendo o "bem comum": taxa de natalidade e mortalidade; expectativa de vida; nascimentos legítimos e ilegítimos e diversos outros aspectos que vão se desdobrar (ao longo

exceções. Um exemplo interessante é a obra Memórias Póstumas de Brás Cubas, de Machado de Assis, publicada em 1881. Apesar de inserir-se na sociedade - ter sido amigo de Alencar e fundador da Academia Brasileira de Letras (ABL) -, Machado era um "pária" para aquela burguesia (mulato, gago, epilético, criado pela madrasta lavadeira). Cria em Cubas o personagem que ironiza o casamento burguês em todos os aspectos: tem uma amante prostituta (Marcela), vive uma inteira trajetória de fracassos, sua relação mais duradoura é um adultério e morre sem deixar descendentes.

2 A Era Vitoriana foi o período no qual a Rainha Vitória reinou sobre a Inglaterra, no século XIX, de junho de 1837 a janeiro de 1901. 
dos séculos XX e XXI) em índices de produtividade, IDH, qualidade de vida, potencial de consumo. Assim resume Foucault (1997, p. 37-38):

Toda esta atenção loquaz com que nos alvoroçamos em torno da sexualidade, há dois ou três séculos, não estaria ordenada em função de uma preocupação elementar: assegurar o povoamento, reproduzir a força de trabalho, reproduzir a forma das relações sociais; em suma, proporcionar uma sexualidade economicamente útil e politicamente conservadora?

Neste cenário, a relação matrimonial e o modelo de família burguesa heterossexual, formada pelo "casal legítimo, monogâmico, fértil", se converte em norma rígida. As instâncias reguladoras de poder se empenham em questionar, perseguir e condenar os "desvios": as sexualidades, os comportamentos ou desejos e as relações não férteis; não convencionais; consideradas "loucas, patológicas, pecadoras ou criminosas".

Introduzimos nesta discussão a voz do sociólogo francês Pierre Bourdieu. Destacamos sua afirmação sobre o homoerotismo como uma forma de sexualidade que se opõe às estruturas do poder, dos jogos de relação de dominação e, sobretudo, da diferença binária do sexo, porque é uma relação de livre troca igualitária, sem sobreposição de um ao outro:

No caso em que, como se dá nas relações homossexuais, a reciprocidade é possível, os laços entre a sexualidade e o poder se desvelam de maneira particularmente clara, e as posições e os papéis assumidos nas relações sexuais, ativos ou passivos principalmente, mostram-se indissociáveis das relações entre as condições sociais que determinam, ao mesmo tempo, sua possibilidade e sua significação. (BOURDIEU, I999, p.3I)

A homossexualidade parece esvaziar a relação de dominação a que ficou presa a oposição masculino/feminino, pois ela é um lugar de desvelamento/revelação de antagonismos institucionalizados, de relações de poder predeterminadas. É uma sexualidade de fronteiras ou sem fronteiras, que 
se desvincula da tradição (mesmo com ela diretamente se relacionando, claro), para instaurar outro modo de se relacionar na vida, diverso das estruturas orgânicas quando percebidas como puramente naturalizadas.

Estas ideias de Bourdieu ecoam a noção de Deleuze quanto à "posição marginal" da homossexualidade como aquela que instaura "o espaço para desconstrução" da identidade de sujeito e do encarceramento das relações de poder e dominância de gênero:

\begin{abstract}
É do fundo de um novo estilo que a homossexualidade produz hoje enunciados que não versam, e não devem versar sobre a própria homossexualidade. Caso se tratasse de dizer "todos os homens são bichas”, isso não é de interesse algum, é proposição nula que só diverte os débeis. Todavia, a posição marginal do homossexual torna possível e necessário que exista algo a ser dito sobre o que não é homossexualidade: "com os movimentos homossexuais, o conjunto dos problemas sexuais dos homens apareceu”. (DELEUZE, 2005, p. 353)
\end{abstract}

Portanto, o "personagem" - que segundo Foucault foi "inventado" no século XIX - "homossexual” começa a produzir e agenciar desejos e enunciados que pulverizam as fixações identitárias. Pode ser aqui lembrada e invocada a metáfora deleuziana do espaço liso, de onde surgem as subjetividades transgressoras. A nomeada homossexualidade se imiscui em espaços lisos e porosos e se afirma como uma alternativa possível de relacionamento(s) na contramão do estabelecido. Mas como se trata de transgressão, insurge nos espaços marginais: “[...] o afastamento geográfico, a procura de lugares diferentes, a inscrição em outros espaços é a condição de uma reconstrução de si.” (ERIBON, 2008, p. 303)

\title{
Minando de dentro: ou quando se evidencia o gênero como uma proliferação de epifanias.
}

Se retomarmos as ideias de Foucault, mais uma vez, quanto à biopolítica, como uma estratégia de controle dos corpos (sexo, gênero, desejo, práticas), fica claro o quanto é fundamental a este exercício de poder a fixação 
identitária como mecanismo de classificação e gerência sociopolítica e econômica, que se verte em todas as formas, inclusive tentando criar "valores culturais" que são meras traduções da moral que se quer manter vigente. A filósofa e professora espanhola Beatriz Preciado - cujo pensamento convidamos agora para esta discussão e acompanharemos mais detalhadamente em seus desdobramentos - avança a partir de sua leitura da biopolítica foucaultiana, ao pensar assim o sexo (o qual pode ser também substituído na sentença a seguir por "gênero"):

O sexo é uma tecnologia de dominação heterossexual que reduz o corpo a zonas erógenas em função de uma distribuição assimétrica de poder entre os gêneros (feminino/ masculino) [...].

A natureza humana é um efeito da tecnologia sexual que reproduz nos corpos, nos espaços e nos discursos a equação natureza = heterossexualidade. O sistema heterossexual é um dispositivo social de produção de feminilidade e masculinidade que opera por divisão e fragmentação do corpo: recorta órgãos e gera zonas de alta intensidade sensitiva e motriz (visual, tátil, olfativa...) que depois identifica como centros naturais e anatômicos da diferença sexual. (PRECIADO, 20I4, p. 25)

A identidade sexual, após se constatarem as armadilhas desta tecnologia biopolítica, pode ser claramente compreendida não como uma expressão "instintiva" e "natural" desta verdade "pré-discursiva" que se tenta atribuir à carne (aos genitais), mas sim como uma série de efeitos de inserção e reinserção das práticas, e das performances, do gênero no corpo 3 . Por isso, aqui, escolhemos permitir que a própria literatura - objeto no qual adentraremos mais para pensar como ele problematiza os enlaces (bomo)parentais - nos fornece uma nova imagem e expressão para melhor matizarmos o fluido universo das identidades (ou identificações) de gênero e sexo: a "epifania".

\footnotetext{
${ }^{3}$ Aqui ecoam ainda as ideias de Preciado (cf. 2014, p. 29).
} 
Etimologicamente, trata-se de uma palavra de origem grega epiphainein e significa manifestação ou aparição. A raiz da palavra (phainein) pode ser traduzida como mostrar, fazer ou aparecer. É um vocábulo muito usado em sentido religioso, como sinônimo de uma manifestação divina. No caso da literatura brasileira, em particular, é impossível desassociar o termo epifania da escritura de Clarice Lispector, que fez deste um verdadeiro momento-chave desencadeador de seu universo diegético. Assim, propomos pensar o gênero e o sexo como verdadeiras epifanias do humano: momentos de revelação, de manifestação e revelação que engendram grande carga significativa, mas não cristalizam e podem se suceder ao longo da vida.

O primeiro fragmento literário destacado por nós foi extraído justamente da irmã de Clarice. No romance No exílio, no qual ficcionaliza a experiência de sua família na fuga ao nazismo (na diáspora judaica), atravessando países até fixar-se no Brasil, Elisa Lispector é autora e matriz com a qual não podemos deixar de identificar (usando das ferramentas legítimas da crítica biográfica) a personagem da filha mais velha, Lizza.É entre esta e o pai (Pinkhas) que se estabelece o seguinte diálogo:

- Lizza, não se pode viver só a vida inteira. Você não é mais criança, é uma moça culta. Ouça-me. Ainda hesitou um pouco, depois prosseguiu. - Sei de um jovem que se interessa por você. Falaram-me nisso, encontrei-o ontem, por acaso, arrematou. E, como visse conturbado o semblante da filha, ajuntou com severidade:

- Lizza, as meninas estão crescidas. É tempo de pensar nelas.

- Case-as, pois, respondeu serenamente. Que não esperem por mim. Talvez, mesmo, nunca me case, concluiu desviando o olhar. O sofrimento do pai the doía, doía-lhe a própria impossibilidade de aquiescer. [...] - Nem todas as familias são iguais, nem toda gente pode viver do mesmo modo. [...] Cada qual deve seguir o seu destino, viver a própria vida. (LISPECTOR, I97I, I54-155, grifos nossos) 
A cena ilustra a filha primogênita que não segue a regra estabelecida: o desejo de casar-se. E é "preciso" que ela o faça, até para que as irmãs mais novas possam casar. Tem-se um exemplo extremo, em que até a hierarquia e sequência de formação de famílias heteronormativas precisa-se seguir (o pai destaca isso "com severidade"). Há "um jovem que se interessa” por ela, mas Lizza fissura o sistema ao questionar e especular que talvez nunca se case. Até se ressente da "própria impossibilidade de aquiescer", mas é lúcida e instaura a dissidência pela afirmação da liberdade de cada indivíduo para seguir seu caminho e, ainda mais, de que "nem todas as famílias são iguais", porque nem todos podem viver do mesmo modo.

E se apenas por não desejar casar-se a personagem Lizza já sente alguma dor, imaginemos o grau de ruptura instaurado pelo vínculo estabelecido entre pessoas do mesmo sexo. Nessa ligação, questiona-se a "essencialidade" heterossexual da procriação e a manutenção da propriedade privada burguesa pela descendência "legítima". Didier Eribon (2008, p. 27) alude a esta questão em seu livro Reflexões sobre a questão gay, logo no capítulo inicial, muito bem intitulado de "O choque da injúria":

\footnotetext{
'Viado nojento' ('sapata nojenta') não são simples palavras lançadas en passant. São agressões verbais que marcam a consciência. São traumatismos sentidos de modo mais ou menos violento no instante, mas que se inscrevem na memória e no corpo (pois a timidez, o constrangimento, a vergonha são atitudes corporais produzidas pela hostilidade do mundo exterior). E uma das consequências da injúria é moldar a relação com os outros e com o mundo. E, por conseguinte, moldar a personalidade, a subjetividade, o próprio ser de um indivíduo.
}

A violência dessas agressões verbais revela o pavor que a contestação aos papéis e scripts estabelecidos representa. A hipótese repressiva de Foucault é retomada nesse excerto de Eribon e, caso adicionemos aqui as reflexões de Beatriz Preciado (20I4, p. 26), podemos observar este corpo sexuado e gendrado como um texto, que compõe o sistema de escritura sexo/gênero: 
O sistema sexo/gênero é um sistema de escritura. $O$ corpo é um texto socialmente construído, um arquivo orgânico da história da humanidade como história da produção-reprodução sexual, na qual certos códigos se naturalizam, outros ficam elípticos e outros são sistematicamente eliminados ou riscados. A (hetero)sexualidade, longe de surgir espontaneamente de cada corpo recém-nascido, deve se inscrever ou se reinstruir através de operações constantes de repetição e recitação dos códigos (masculino e feminino) socialmente investidos como naturais.

Preciado denuncia com muita argúcia o quão arbitrário é o sistema social de engendramento do sexo, do gênero, das prisões que inflige ao corpo. E a operação de identificação com as noções de sistema de escritura e texto são muito fecundas para o diálogo que estamos estabelecendo entre a literatura e o terreno político-social das formações familiares. Seguindo sua proposição demolidora, Preciado elabora a noção da contrassexualidade, cuja tarefa é identificar os espaços considerados errôneos ("as falhas da estrutura do texto") e reforçar o poder dos desvios e derivações com relação ao sistema "heterocentrado". É preciso, portanto, "sacudir as tecnologias da escritura do sexo e do gênero, assim como suas instituições". (PRECIADO, 20I4, p. 27) Ao se modificarem as posições de enunciação, ou seja, ao experimentar e evidenciar as "epifanias do sexo, de gênero e do corpo", é produzido ruído necessário para desestabilizar o cristalizado edifício das identidades fixadas.

Discutindo o pós-humano e o caráter "prostético" de invenção e fabricação dos corpos (cujo gênero se configura efetivamente na materialidade dos corpos, no entanto esta materialidade é cada dia mais resultado de próteses, tecnologias, modificações estéticas ou funcionais), Preciado revela o quanto há tanto de orgânico quanto de tecnologia na fabricação sexual dos corpos: próteses de silicone, maquiagens, adereços, atividades físicas para moldar músculos. Vem, então, a proposição da contrassexualidade, para reivindicar "a compreensão do sexo e do gênero como cibertecnologias complexas do corpo”. (PRECIADO, 20I4, p. 40) E, invocando a teórica 
feminista Donna Haraway, propõe-se "uma queerização urgente da 'natureza”. (PRECIADO, 20I4, p. 40)

É trazido à discussão o termo "queer": em sua origem a expressão traz carga ofensiva para designar "estranho" ou “esquisito” em relação a um homossexual; reapropriada pela teoria de gênero ligada às correntes de estudos gays e pós-identidade, revela a força política de uma citação descontextualizada de um insulto homofóbico e da inversão de posições de enunciação hegemônicas que este provoca e é assimilada como subversão e autodefinição, não mais como ofensa.

David Halperin, em seu Saint Foucault: towards a gay bagiograpby (cf. I995, p. 86), apropriando-se do termo “queer”, propõe a expressão “queer práxis” para designar a transformação de certas técnicas de dominação em "técnicas de si”, as quais poderíamos entender como modos de construção de identidade que instauram lugares de resistência à dominação. Entre as principais metas do Manifesto Contrassexual, está justamente "aprender a subverter os órgãos sexuais e suas reações biopolíticas”. (PRECIADO, 20I4, p. 59) Através de uma operação nomeada de "inversão-investidura”, desloca-se a força da performatividade do código heterocentrado e se provoca "uma per-versão, uma reviravolta na produção habitual dos efeitos da atividade sexual”. (PRECIADO, 20I4, p. 6o, grifo nosso)

Para descolonizar o sexo, o corpo e o gênero, a contrassexualidade aponta para "práticas contrassexuais como possibilidades de uma deriva radical em relação ao sistema sexo/ gênero dominante" (PRECIADO, 20I4, p. 3I), uma fundamental delas é a "erotização do ânus": banido da lógica erótica heteronormativa, pois é o lugar comum de todo corpo (independente de genitália e binarismo), além de ser centro erógeno, é identificado como zona de passividade e produtor - ao mesmo tempo-de excitação, prazer e de excreção:

O trabalho do ânus não é destinado à reprodução nem está baseado numa relação romântica. Ele gera benefícios que não podem ser medidos dentro de uma economia heterocentrada. Pelo ânus, o sistema 
tradicional da representação sexo/ gênero vai à merda. (PRECIADO, 20I4, P. 32)

É, pois, esta parte comum a todos os corpos um lugar "revolucionário" em essência: sempre que protagonista de prazer ou excitação, desestabiliza as "etiquetas" e a norma dos "bons costumes". É exatamente esta potência que a escritora paulista Hilda Hilst reconhece ao enunciar seus questionamentos metafísicos, na novela $A$ Obscena senbora $D$ :

\begin{abstract}
Ai, Senhor, tu tens igual a nós o fétido buraco? Escondido atrás mas quantas vezes pensado, escondido atrás, todo espremido, humilde mas demolidor de vaidades, impossível ao homem se pensar espirro do divino tendo esse luxo atrás [...], trejeitos, cabeleiras, mas o buraco ali, pensaste nisso? Ó buraco, estás aí também no teu Senhor? Há muito que se louva o todo espremido. Estás destronado, quem sabe, Senhor, em favor desse buraco? (HILST, 1993, p. 54)
\end{abstract}

Humilde e demolidor de vaidades, o ânus é o denominador comum de todos os seres humanos e desses com o divino. A lucidez destas declarações faz da personagem uma "louca" de tão lúcida, proscrita do bom convívio social hipócrita. E também banidos do convívio social se veem outros dois personagens de Hilst, em Rútilo Nada, outra de suas densas e provocativas criações na qual se estabelece uma trágica família destoante dos moldes heteronormativos. Lucius Kod é o jornalista de 35 anos (filho de um banqueiro bem-sucedido) que se descobre apaixonado por Lucas, namorado de sua filha. Enredo trágico (a própria autora invoca na narrativa um costume da clássica cidade grega de Cartago, em que sogro e genro não se podiam separar) que desnuda o quanto o comportamento moralista heteronormativo reage e condena qualquer desvio a suas normas. Lucius é agredido pelo pai. Assim explode a reação do banqueiro ao envolvimento afetivo do filho com o namorado da neta:

[...] então anos de decência e de luta por água abaixo e eu um banqueiro, com que cara você acha que eu vou aparecer diante de meus 
amigos, ou você imagina que ninguém sabia, crápula, canalha, tua sórdida ligação, e esse moleque bonito era o namoradinho da minha neta [...]. gosta de cu seu canalha? gosta de merda? fez-se também de mulherzinha com o moço machão? (HILST, I993, p. I4- 15)

Saliente-se que este mesmo banqueiro beija os lábios do "moleque bonito" Lucas, quando vai conferir o "serviço de espancamento" que manda seus capangas executarem e em decorrência do qual o rapaz acaba por morrer. É verbalizada por Lucas a "dor de não ter sido igual a todos" (I993, p. 24) - volta a figura da injúria e da agressão já mencionada por Eribon - e resta a Lucius o desencanto de reconhecer-se, mas ser proscrito, e o desencaixe na identificação binária, estereotipada: "Eu não sou o que sou, fico me repetindo, nem fêmea alguma e macho muito menos me colocaram aqui neste tempo onde estou, tempo desordenado, avessos de um rumo [...]”. (1993, p. 2I).

Fica evidente o quanto qualquer definição é uma limitação, impede as sucessivas epifanias/revelações do ser em suas relações com seu corpo/gênero/sexo e suas práticas de afeto. Cabe, pois, aos escritores expandirem seus alcances. Foi assim também com Caio Fernando Abreu, ficcionista e dramaturgo gaúcho, jornalista, ator, vítima da Doença da Imunodeficiência Adquirida (Aids) em um momento de estigmatização desta como uma doença gay. Sua obra revela as uniões que escapam da formação familiar burguesa heteronormativa e frequentemente seus personagens traduzem o desencaixe social: a vida nos guetos ou, emblematicamente, como diz a personagem-narradora do conto "A Dama da Noite": "Você tem um passe para a roda-gigante, uma senha, um código, sei lá. [...] então o cara deixa você entrar, sentar e rodar junto com os outros. Mas eu fico sempre do lado de fora." (ABREU, I988, p. 9I) É a voz de uma travesti em um bar, à noite: único lugar em que ela pode circular. $\mathrm{O}$ título do livro no qual consta este texto é Os dragões não conbecem o paraíso, metáfora a traduzir o quão outsiders são esses seres "exóticos” da fauna desviante. 
E se pensamos em o quanto a simples existência de comportamentos e a produção de desejos que não seguem, que questionam ou contrariam a norma causam de desestabilizações na ordem social, imagine-se o que causa uma família como a que cria e propõe o ficcionista, dramaturgo, ator e desenhista argentino Raul Botana (o qual assinava sob o pseudônimo Copi) ao criar obras como: L'Homosexual ou La difficulté de s'exprimer (ou O Homossexual ou a dificuldade de expressar-se), em que a personagem Irina - espécie de protagonista e centro dramático - é uma transexual filha de outra transexual que é, na verdade, sua mãe, e também é seu/sua amante e nada tem de parentesco sanguíneo com ela.

GARBO: Onde conheceste madame Simpson, Irina?

IRINA: No Egito.

GARBO: Ela realmente tem algum grau de parentesco contigo?

IRINA: Não.

GARBO: Por que tu estás com ela? Ela decidiu por ela mesma ser tua mãe e tu aceitaste sem pestanejar?

IRINA: Sim. (1984: 7I-72, tradução nossa do original francês) ${ }^{4}$

E há muito mais. São cinco personagens: além de Irina e sua mãe (Madame Simpson), Madame Garbo (professora de piano e amante de Irina; também transexual, tem um pênis), o oficial Garbenko (marido dessa) e o general Pouchkine. O cenário é a Sibéria. Irina é o centro em torno da qual gravitam todas as relações e as outras personagens.

Irina está grávida, não se sabe de quem: ora ela afirma ser de sua mãe (Madame Simpson), ora de Madame Garbo (sua amante e professora de

4 Garbo: Où est-que tu as connu madame Simpson, Irina?

Irina: En Égypte.

Garbo: Est-ce qu'elle a un vrai lien de parenté avec toi?

Irina: Non.

Garbo: Pourquoi es-tu avec elle? Elle a décidé comme ça d'être ta mère et tu l'as suivie? Irina: oui. (1998: 71-72) 
piano), ora de um travesti "pequeno e louro" com quem fornica nos banheiros da estação de trem, ora do oficial Garbenko. Mas Irina "defeca” o bebê. Sim, ela o aborta pelas vias fecais (provavelmente por onde recebe esperma, sendo uma homossexual/transexual de homem para mulher).

Em trecho de diálogo em que Madame Garbo questiona Irina sobre a sua decisão pela mudança de sexo, constatamos como ecoa nossa proposição do gênero como epifania e, também, os princípios que devem reger uma sociedade contrassexual, segundo Preciado, na qual as explorações das diversas mudanças de sexo/gênero devem ser franqueadas:

GARBO: Por que mudaste de sexo?

IRINA: Eu já tinha começado.

GARBO: Mas tu tinhas apenas colocado seios. No início, não querias mudar de sexo.

IRINA: Mas depois eu quis mudar de sexo.

GARBO: Por quê?

IRINA: Eu já tinha começado.

GARBO: Por que tu quiseste pôr seios?

IRINA: Eu queria ter seios.

GARBO: E tu não querias mudar de sexo.

IRINA: Não.

GARBO: Então, foi depois de conhecer madame Simpson que tu quiseste mudar de sexo. Foi madame Simpson quem te pediu para mudar de sexo?

IRINA: Não.

GARBO: Foi o tio Pierre?

IRINA: Não.

GARBO: E quem foi? 
IRINA: Ninguém. Eu mesma quis mudar de sexo. Ninguém me sugeriu isso.

GARBO: Tu me disseste que no começo não querias mudar de sexo. Tu só querias pôr seios. Só depois de conhecer madame Simpson e tio Pierre foi que quiseste mudar de sexo. Por quê?

IRINA: Não sei.

GARBO: Deve haver uma razão. Tente achá-la. Por quê?

IRINA: Eu queria mudar de sexo.

GARBO: Tu querias ter um sexo de mulher em vez de um sexo de homem?

IRINA: Sim, foi isso.

GARBO: Mas, por quê?

IRINA: Porque eu queria. (I998: 83-86, tradução nossa) ${ }^{5}$

${ }^{5}$ Garbo: Pourquoi as-tu changé de sexe?

Irina: J'avais déjà commencé.

Garbo: Mais tu t'étais fait seulement pousser les seins. Au début, tu ne voulais pas changer de sexe.

Irina: Mais plus tard, j'ai voulu changer de sexe.

Garbo: Pourquoi?

Irina: J'avais déjà commencé.

Garbo: Pourquoi est-ce que tu t'es fait pousser les seins?

Irina: Je voulais avoir des seins.

Garbo: Et tu ne voulais pas changer de sexe.

Irina: Non.

Garbo: Alors c'est après avoir connu madame Simpson que tu as voulu changer de sexe.

C'est madame Simpson qui t'a demande de changer de sexe?

Irina: Non.

Garbo: C'est l'oncle Pierre.

Irina: Non.

Garbo: C'est qui?

Irina: C'est personne. J'ai voulu changer de sexe toute seule. Personne ne me l'a dit.

Garbo: Tu m'as dit qu'au début tu ne voulait pas changer de sexe. Tu ne voulais pas changer de sexe. Tu ne voulais que te faire pousser les seins. Ce n'est qu'après avoir connu madame Simpson et l'oncle Pierre que tu as voulu changer de sexe. Pourquoi?

Irina: Je ne sais pas. 
Voltando ao enredo da peça e à ideia de reprodução, Madame Garbo também teve um bebê, em seu passado. Era uma mulher e tem um filho que rejeita e mata. Como castigo, seu pai a faz receber o implante de um pênis e ela se torna mais uma transexual desta galeria de Copi. Seu marido, o oficial Garbenko, a ama mesmo assim, mas é muito compreensivo (apesar de também ser amante de Irina), quando Madame Garbo resolve admitir sua paixão por Irina e pede a ele ajuda para fugir com sua amada para a China. Vale salientar que a mãe de Irina (Madame Simpson) irá junto. Por fim, tudo é apresentado com um humor afinado e que não perde ritmo. Irina, porém, encerra a peça cortando a própria língua: talvez para ilustrar a dificuldade de expressar o que é toda esta liberdade de poder se construir a tecnologia do corpo contrassexual conforme suas epifanias. Destaque-se ser uma dramaturgia de i97i que põe em cena literalmente muito do que irá teorizar nos anos 2000 a filósofa Beatriz Preciado.

Copi nasceu em Buenos Aires em 1939, filho de uma família ligada ao jornalismo, à política e às artes. Seu avô materno era Natalio Botana, fundador e diretor do Diário Crítica, lendário jornal argentino. A avó materna era Salvadora Medina Onrúbia, já mãe solteira de um filho quando se casa com Natalio, dramaturga, envolvida em casos fortuitos de lesbianismo. Dela vem o apelido com que o neto se tornaria conhecido. Aliás, apelidava todos os filhos e netos para evitar que fossem enfeitiçados. O pai de Copi, Raul Taborda, era jornalista e artista plástico. Durante a ditadura peronista, opôs-se radicalmente ao general Perón e toda a família acabou por precisar se exilar. Copi chegou a Paris com I6 anos de idade, onde se fixou até morrer em 1987, em decorrência da Aids. Convenhamos: também não se tratava de uma família muito convencional a deste escritor, que tinha o

\footnotetext{
Garbo: Il doit y avoir une raison. Essaie de la trouver. Pourquoi? Irina: Je voulais changer de sexe.

Garbo: Tu voulais avoir um sexe de femme au lieu d'um sexe d'homme?

Irina: Oui, c'est ça.

Garbo: Mais pourquoi?

Irina: Parce que je voulais. (1998, 83-86)
} 
hábito de nomear diversos de seus personagens com seu próprio apelido, o que aponta para o extremo grau de ficcionalização de si que praticava.

Suas criações envolvem frequentemente a quebra de paradigmas e fronteiras; suas personagens podem ser gays, lésbicas, heterossexuais, animais. Travestir-se, cambiar-se é a operação fundamental em sua galeria de criaturas; como ele próprio atuando. Em várias entrevistas era questionado sobre sua (homo)sexualidade e respondia que esta não era uma "condição forçosa” e muito menos que moldava sua visão de mundo; também respondeu ironicamente quando inquirido sobre se quis ter filhos:

Depois estão os filhos de todo mundo, são filhos meus; não tenho uma frustração de paternidade, pelo contrário, penso que os filhos dos meus amigos [...] são muito amigos meus e de alguma forma mais ainda que seus pais; de certo modo, em algum nível argentino, eu seria 'a tia Marica', isso existe, isso existe. ${ }^{6}$

Além de transgressor em sua obra, dava declarações provocativas nas entrevistas: invocava a urgência da questão feminina na Argentina (país de larga tradição patriarcal machista); afirmava o quanto adorava fazer-se de travesti no teatro (encantava-se de atuar em trajes femininos; mas também ao travestir-se em animal) e, ainda, ao afirmar que as travestis é que se vestiam como mulheres (nos anos I970 e I980) e que ser mulher não era simplesmente ter "um par de tetas" ou uma vagina (genitais normatizados como femininos); pois isso ele também tinha. São tão somente zonas erógenas e o sexo está para além das prisões fixas das identidades normativas e dos genitais assim compreendidos.

Talvez por este ambiente de maior liberdade, sempre o clã familiar criado por Copi desempenha seus papéis e as relações sob a inflexão das epifanias de gênero e sem restrição alguma. No romance La Guerre des Pédés (ou A Guerra

${ }^{6}$ Después están los hijos de todo el mundo, son hijos mios; no tengo una frustración de paternidad, al contrario, pienso que los hijos de mis amigos [...] son muy amigos mios y de alguna manera más que sus padres; de cierto modo, en algún nível argentino sería 'la tia Marica', eso existe... eso existe. (TCHERKASKI, 1998, p. 44) 
dos Pederastas), a idealização de uma família perfeita é proposta: a Brigada Interespacial Homossexualé um grupo ativista gay que procura melhor rumo para a sociedade. Para tanto, encontra o personagem Copi e o convence de que ele precisa procriar com outra personagem: uma brasileira do Amazonas, hermafrodita perfeita, chamada Conceição do Mundo (nome literalmente simbólico: a concebedora do mundo, do novo mundo a vir). E se pergunta o personagem Copi, sob a ironia mordaz do autor: "Que espécie de filho poderei ter, eu, pobre homossexual que jamais sonhei em me reproduzir?" (I982, p. I48, tradução nossa).? Mas este personagem será "o primeiro herói gay sobre a Lua” (I982,p. 159), justamente por principiar um novo mundo.

Do enlace entre Copi e Conceição do Mundo nascerá o primeiro "Homossexual sapiens" e irão povoar a lua a partir deste primevo clã de peculiares novos "Adão e Eva”, pois a terra já não parece mais ter cura de sua doente sociedade heterossexista hipócrita, falso-moralista e castradora. $\mathrm{O}$ chefe da Brigada Homossexual, fincada a bandeira gay na lua, sentencia esta criação de um novo mundo possível, muito melhor e mais liberto: "Sei que levaremos muito, muito tempo para compreender, mas de agora em diante nós nos encontramos na realidade do Universo e não naquela da nossa Terra; nós estamos na Utopia, Copi!” (COPI, I982, p. I67). ${ }^{8} \mathrm{E}$ a utopia é o pleno exercício de existir em liberdade.

\section{Das vias abertas às permanentes inconclusões}

Se relembrarmos a declaração do personagem Lucius Kod (I993, p. 2I), (de Hilda Hilst, citada anteriormente), quando se diz "nem fêmea nem macho", mas um ser complexo colocado em um "tempo desordenado", como "avessos de um rumo" não podemos evitar o apontamento cons-

7 Quelle sorte de fils allais-je avoir, moi, pauvre homosexuel qui n'aurais jamais songé à me reproduire? (1982: 148)

8 - Je sais que l'on met très, très long temps à le comprendre, mais désormais nous nous trouvons dans la réalité de l'Univers et non dans celle de notre Terre; nous sommes dans I'Utopie, Copi! (1982: 167). 
ciente de que algo está errado nesta ordem que desrespeita os seres em sua potência.

Muito precisamente toca nesse mesmo ponto Alberto Manguel (2000, p. 35):

Todo grupo que é objeto de preconceito tem isto a dizer: somos a língua em que somos falados, somos as imagens em que somos reconhecidos, somos a história que somos condenados a lembrar porque fomos barrados de um papel ativo no presente. Mas somos também a língua em que questionamos essas pressuposições, as imagens com que invalidamos os estereótipos. E somos também o tempo em que vivemos, um tempo de que não podemos nos ausentar. Temos uma existência própria, e não estamos mais dispostos a permanecer imaginários.

O objeto artístico é transtemporal (inscreve-se em seu contexto de produção, mas torna-se "presentificável” a cada nova fruição) e acorda o leitor ou o público da anestesia, para fazê-lo despertar e reconhecer que seu papel social é, também, crítico e político, ao fazer sua "leitura a contrapelo”. As obras e as vozes de seus criadores aqui trazidas à cena revelam a mesma urgência: desmascarar a norma instituída e a falácia que representa um estereótipo único e pasteurizado de parentalidade. Instauram-se, pois, nesses universos artísticos, novos e melhores "mundos possíveis" para seres que são humanos e "pós-humanos" e querem simplesmente ser, exercer-se e viver.

\section{Referência}

ABREU, C. F. Os dragões não conbecem o paraíso. São Paulo: Cia. das Letras, 1988. BOURDIEU, P. A dominação masculina. Rio de Janeiro: Bertrand Brasil, 1999. 
COPI. L'Homosexuel ou La difficulté de s'exprimer. Paris: Christian Bourgois, 1998.

COPI. La Guerre des Pédés. Paris: Albin Michel, 1982.

DELEUZE, G. Ilha deserta. São Paulo: Iluminuras, 2005.

ERIBON, D. Reflexões sobre a questão gay. Rio de Janeiro: Companhia Freud, 2008.

FOUCAULT, M. História da sexualidade I: a vontade de saber. Rio de Janeiro:

Graal, 1997 .

GOMES, R. C. Todas as cidades, a cidade. Rio de Janeiro: Rocco, 1994.

HALPERIN, D. Saint Foucault: towards a gay hagiography. New York: Oxford University Press, 1995.

HILST, H. Rútilo nada/ A obscena senbora D./ Qadós. São Paulo: Pontes, 1993.

LISPECTOR, E. No exilio. 2. ed. Brasília: Ebrasa, I97I.

MANGEL, A. No bosque do espelbo: ensaios sobre as palavras e o mundo. São

Paulo: Cia. das Letras, 2000.

PRECIADO, B. Manifesto contrassexual: práticas subversivas de identidade sexual. São Paulo: n-I, 2014.

TCHERKASKI, J. Habla Copi: homosexualidad y creación. Buenos Aires:

Galerna, 1998. 